Revue d'études américaines. American Studies Journal

\title{
Can Literature Know Itself and Not Become Philosophy?
}

Ralph M. Berry

(2) OpenEdition

Journals

Electronic version

URL: https://journals.openedition.org/transatlantica/15428

DOI: 10.4000/transatlantica. 15428

ISSN: 1765-2766

Publisher

Association française d'Etudes Américaines (AFEA)

Electronic reference

Ralph M. Berry, "Can Literature Know Itself and Not Become Philosophy?", Transatlantica [Online], 1 I 2020, Online since 01 December 2020, connection on 01 February 2023. URL: http://

journals.openedition.org/transatlantica/15428 ; DOI: https://doi.org/10.4000/transatlantica. 15428

This text was automatically generated on 1 February 2023.

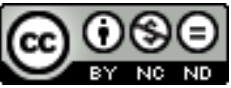

Creative Commons - Attribution-NonCommercial-NoDerivatives 4.0 International - CC BY-NC-ND 4.0

https://creativecommons.org/licenses/by-nc-nd/4.0/ 


\title{
Can Literature Know Itself and Not Become Philosophy?
}

\author{
Ralph M. Berry
}

\author{
“[...] in a modern era intellectual works with \\ designs upon the most serious attention of their \\ culture must give themselves out as, or allow \\ themselves to be appropriated as, philosophies." \\ Stanley Cavell, The Claim of Reason (1979b xxi)
}

I want to begin by acknowledging an unusual characteristic of both literature and philosophy, namely, that no one seems to know what either is-or at least that no one seems able to say what either is, or not with any authority, when the concept of either is questioned. Part of what I have in mind is the divide between philosophy's continental and Anglo-American versions, a depth of disagreement that philosophers seem able to explain only tendentiously, that is, by aligning themselves with one version against the other. And my other point of reference is literary criticism's disenchantment with poetics, by which I mean the attempt to abstract the constituents of literariness from their various historical manifestations, whether we consider this project in the terms of structural linguistics, the American New Criticism, or aesthetic theory generally. In both cases, a limit on our knowledge, or perhaps on our ability to express what we know, seems to have been confronted, and even if these limits are now familiar, I don't think they are very well understood. When in his 1932 essay, "The Elimination of Metaphysics through the Logical Analysis of Language," Rudolf Carnap criticizes Heidegger's philosophy, he does not simply accuse Heidegger of making mistakes. He accuses him of being no philosopher at all, of uttering sentences that are cognitively meaningless; and when in "Reiterating the Difference" in 1977 John Searle charges Derrida with obscurantism, his similar implication is that, more than just fallacious, deconstruction amounts to charlatanry. I am suggesting that, contrary to the dominant narrative of American English departments, there is a bond between this kind of repudiation and the challenge to aesthetic universality mounted by politically minded critics in the sixties and seventies, a challenge embodied in Raymond Williams's statement, also made in 1977 , that 'It is relatively difficult to see 'literature' 
as a concept" (Williams, 1977 45). In both cases, that of philosophy and literature, the attempt to provide a comprehensive account of one's undertaking, an account that could without prejudice also include versions unlike one's own, gives way to a more historically and culturally situated practice, one that acknowledges certain limits on the possibility of making oneself understood. Although I have been convinced by Stanley Cavell's account of these issues-by which I mean an account of literature and philosophy in which the limits of knowledge are set by self-knowledge, both one's own and that of those with whom one wishes to communicate ${ }^{1}-$ my aim is not to take sides. It is to understand these limits we have confronted. What does it mean to have a concept that I routinely apply, calling certain things philosophy or literature as a matter of course, but that, as soon as I am challenged, I can neither define nor defend, or not to any challenger's satisfaction?

2 Section $\$ 77$ is one of the few passages in Wittgenstein's Philosophical Investigations where, in his account of our conceptual knowledge, Wittgenstein takes up aesthetic concepts directly-that is, where he addresses what it means for someone to know what a portrait, plot, crescendo, or ode is (40-41). In the preceding sections (\$67-\$71), he has described two ways in which we operate with concepts. According to the first, we formulate context-specific rules for a concept, establishing definite boundaries on its application, and in the second we express our conceptual knowledge unselfconsciously, in an open-ended and improvisatory practice. Wittgenstein's point is not that one of these ways is superior. His point is that any concept will in different circumstances require greater or less definiteness and also that, in the circumstances with which we are most familiar, different concepts will ordinarily require greater or less definiteness. In section $\$ 68$ he says that we apply our concept of a number-that is, use the word "number"-in both the rule-governed and open-ended ways, while we ordinarily use the word "game" only in the second, and in a characteristically vivid image (\$76), he compares these two versions of conceptualization to two pictures, one of which is composed of colored squares with sharp edges and the other of colored squares with blurred edges. (See figure \#1.) 
Figure \# 1

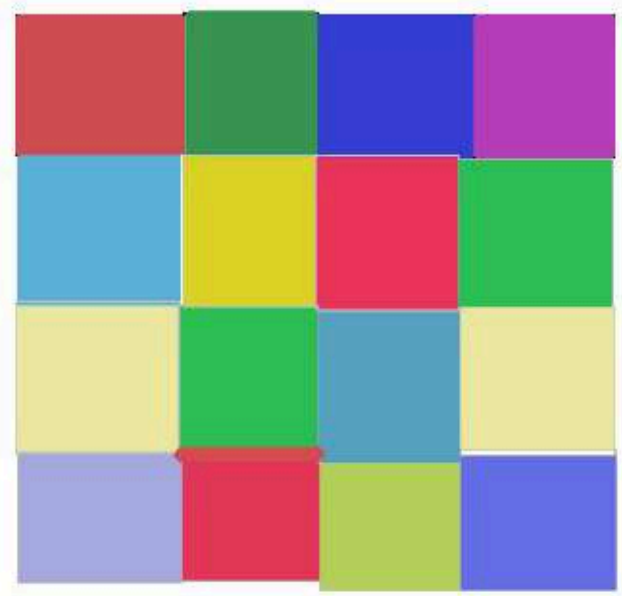

3 Describing the sharp picture's resemblance to the blurred as that of a definition to an unselfconsciously deployed concept, Wittgenstein goes on in $\$ 77$ to consider a third version of conceptualization (see figure \#2), one in which the blurred picture becomes so blurry that it loses all resemblance to the sharp: 
But if the colors in the [blurred picture] shade into one another without a hint of any boundary, won't it become a hopeless task to draw a sharp picture corresponding to the blurred one? Won't you then have to say: 'Here I might just as well draw a circle as a rectangle or a heart, for all the colors merge. Anything-and nothing-is right.'

Figure \#2

Wittgenstein's implication seems to be that, were our concepts when unselfconsciously deployed to lack all definiteness, their application would appear so random that, if anyone failed to understand what I meant in calling something a game, no contextspecific definition would seem relevant. And then comes Wittgenstein's punchline: "And this is the position in which [...] someone finds himself in ethics or aesthetics when he looks for definitions that correspond to our concepts."

5 I have never been sure whether Wittgenstein intends this sentence as one of his gloomy pronouncements on modernity, when in his view confusions are so endemic that much of fundamental importance goes unrecognized, or whether he means it as an acknowledgment of how-not just during modernity, but at any time-our knowledge of art and morality differs from our knowledge of numbers and games. Of course, there is another possibility, one Wittgenstein may have in mind in sections \$122 and \$129, namely, that the confusions of our time are so endemic that, unless the operation of our concepts is laid bare, affording us a view of their relations at any time, what is of fundamental importance will go unrecognized. But, regardless of how or whether we historicize it, Wittgenstein's picture of our aesthetic concepts seems pretty unsettling. His implication seems to be that, unlike both the sharply defined concepts of mathematics and the blurry concepts of play, our knowledge of music, painting, sculpture, drama, film, television, architecture, dance, and literature-at least as embodied in the language we speak-is just formless, has no shape at all. Wittgenstein's 
remark occurs in that part of Philosophical Investigations where he rejects the idea that everything grouped under a concept has one essential feature in common (\$65), an idea that was central to his earlier explanation of language in the Tractatus. Now he claims that the various exemplifications of a concept are related to one another in the way the members of a family are related, that is, by "a complicated network of similarities" in which what we call a game or a number depends on its resemblances to other things we call games or numbers (\$66-\$67). The idea is that no common feature explains why we call football, chess, and poker games, not because in reality they have no common features, but because their various resemblances strike us as sufficiently obvious that in ordinary circumstances we group them together as a matter of course, without need for greater definiteness. However, in circumstances where we do need greater definiteness, that is, where I am unsure what my friend means in saying that her marriage has turned into a game, a context-specific definition can usually be formulated. She might say, for example, "By a game, I just mean we're always keeping score," or "It seems like a game because we're both trying to win." As Stanley Cavell has shown, learning when such explanations are needed and how to provide them is part of what we learn in learning a word (Cavell, 1969 1-43, 62-70). It gives our concepts their distinctive shape.

6 Why then does Wittgenstein think that the family resemblances among art works are insufficient to give a similarly recognizable shape to our aesthetic concepts? What is lacking about my knowledge of what a theme, fugue, or tour jeté is, that my knowledge of games provides? It is worth noting that in Philosophical Investigations the formlessness that in section $\$ 77$ Wittgenstein attributes to our aesthetic concepts seems to afflict all of our concepts as soon as philosophy gets hold of them. Wittgenstein compares doing philosophy to forgetting what one knows (\$89), losing one's footing (\$107), getting turned around (\$108), feeling disoriented (\$123), becoming entangled in rules (\$125), or regressing to a primitive state (\$194), and he thinks this alienation is likely to beset us any time we try to define our concepts in circumstances where they require no greater definiteness, that is, in the absence of any particular misunderstanding that contextspecific rules, definitions, or boundaries could straighten out. If, for example, I ask why chess is called a game, not because there's something about chess that I do not understand, nor because I fail to see any resemblances to football and poker, but because I want to know how the concept of a game is applied at any time, then Wittgenstein thinks the boundary between chess and related concepts-say, warfare or politics-rather than just blurry, will start to look artificial, as though corresponding to nothing real. After all, is it really so obvious that moving the knight in chess resembles kicking a ball at a goal more than deploying troops on a battlefield? When we look at meaning in this way, Wittgenstein believes that our concepts will tend to merge, such that-were I Raskolnikov and prepared to act on my philosophizing-as soon as you reached for my queen, I might attack you, and no rule of the game of chess could convince me I was making a mistake. What, prior to philosophy, looked like the sharpest imaginable boundary, that between mere amusement and aggression, after philosophy resembles an undifferentiated continuum, one on which games and wars constitute so many randomly distributed points. Although any definition might be imposed onto this picture, none fits it. In fact, it is just this lack of fit that philosophy has seemed to expose. In other words, the effect of doing philosophy, according to Wittgenstein, is to make concepts that we ordinarily apply as a matter of coursewithout need for rules or definitions, in an open-ended and improvisatory practice- 
look like conventions, habits, and trained reflexes, that is, like actions we perform merely as a matter of social conformity.

It now becomes somewhat clearer why Wittgenstein pictures our aesthetic concepts as shapeless. Unlike numbers or games, works of art-paintings, musical compositions, novels, poems-have often raised questions about what our aesthetic concepts mean, and not only in circumstances where their resemblances to other things called paintings, music, or literature have been less than obvious. When in 1884 Henry James sets out to explain the art of fiction without recourse to the rules of Walter Besant or the metaphysical strictures of French naturalism (James, 1986), he undergoes a loss of footing similar to what Wittgenstein describes philosophy producing (Berry, 2003), much as does Virginia Woolf forty years later when she accuses the novelists of Arnold Bennett's generation of substituting mere externals for the novel's proper work. "It is to express character [...] that the form of the novel [...] has been evolved," she declares, only to concede that she cannot say what, apart from externals, character is (Woolf, 1993 238). A similar philosophical disorientation occurs when in 1927 E.M. Forster pronounces Gertrude Stein's fiction a failure, claiming that "the basis of a novel [...] is a narrative of events arranged in time sequence" (Forster, 1927 30), a claim that Stein's account of temporality in "Composition as Explanation" (Stein, 1990) does not so much challenge as sublime, making it all but impossible to say what the phrase "time sequence" means. And this list, if continued, could include Theodor Adorno's quarrel with Georg Lukács over the putatively fundamental status of narrative realism (Adorno, 1998), Roland Barthes's challenge in Writing Degree Zero to Jean Paul Sartre's placing political boundaries on fiction's development (Barthes, 1977), and the various debates from the 1960s to the present over anti-novels, metafiction, the nouveau roman, magic realism, Oulipian narrative, écriture feminine, and conceptual writing-to mention only well-known cases.

What seems most striking about these examples, at least from Wittgenstein's viewpoint, is that in none of them do rules, definitions, or boundaries function to straighten out misunderstandings, or not as they do in the case of games, that is, by explaining how in a specific context a concept is being applied. On the contrary, no party to the disagreements actually appears confused about whether the works in question are novels or not-at least no one hesitates to refer to them as novels-as though the difficulty experienced by Besant, Bennett, Forster, Lukács, and Sartre were less to recognize family resemblances than to ignore them, especially those that, if not for their rules, definitions, and boundaries, might appear obvious. However, the contrasting explanations offered by James, Woolf, Stein, Adorno, and Barthes seem so lacking in definiteness that, were there any real misunderstanding-that is, were anyone really confused about how to do with the works in question what people have in the past done with novels-little they say about what a novel is would help. Instead, the principal effect of their explanations is to expose the artificiality of the rules and definitions put forward by Besant et al, transforming the novel's conventional boundaries into what looks more like an undifferentiated continuum. In other words, these disagreements appear as much philosophical as aesthetic, consisting of contrasting pictures of how at any time the concept of a novel is deployed. In the first, the concept's boundaries appear sharp precisely because they bear little or no relation to how the word "novel" is actually used, while in the second, the boundaries appear so blurry that hardly any novel could be said either to fit it or to fail to fit it. What seems altogether missing is Wittgenstein's picture of a concept's unselfconscious, open-ended 
deployment, a picture in which, despite blurred edges, meaning looks sufficiently definite-both to ourselves and others-that misunderstandings can ordinarily be overcome. $^{2}$

9 In Philosophical Investigations \$77, Wittgenstein offers uncharacteristically direct advice to all who, in aesthetics or ethics, find themselves in the predicament of James, Woolf, Forster, or Stein-that is, in circumstances where a concept has begun to look so formless, or its boundaries so artificial, that its meaning strikes us as questionable at any time. Instead of trying to formulate definitions or rules, Wittgenstein tells us, we should ask ourselves: "How did we learn the meaning of this word ('good' for instance)? From what sort of examples?" (\$77). The purpose of his advice is not to make what we have in the past called paintings, music, or literature a limit on how we presently apply these concepts, although Wittgenstein does take seriously our need to learn a concept before changing it. However, his aim is not conservative. It is to prevent us, whenever our aesthetic concepts are questioned, from constructing explanations satisfying to no one, not even ourselves. That is, the problem in $\$ 77$ is not that we lack definitions sufficiently expansive to include works unlike those we already know. It is that, although we call various things novels as a matter of course, our explanations of what we mean bear little relation to what strikes anyone as fundamentally important. In other words, the problem in $\$ 77$ has less to do with the limits of our aesthetic concepts than with their basis, the grounds to which we ordinarily take recourse, not to explain why something is or is not a novel, but to explain why it is or is not a good one. When Wittgenstein advises us to turn away from definitions and toward examples, his point is that what we seem confused about is how we actually deploy our aesthetic concepts, not just how we explain them, and when he specifies examples of the kind from which we learned the terms of aesthetic judgments, his point is that, to overcome confusion, our concepts must stop looking as they do when philosophy gets hold of them, that is, as though their boundaries were artificial, corresponded to nothing real. That aesthetic concepts change does not make them different from any other concepts. What makes them different is that in circumstances like those in which James, Woolf, Forster, and Stein find themselves, specifying a family resemblance rarely satisfies anyone. To change an aesthetic concept, our deployment of it cannot look merely conventional. It has to function as exemplary. ${ }^{3}$

When in "Mr. Bennett and Mrs. Brown," Virginia Woolf complains that the novelists of her generation had "no English novelist living from whom they could learn their business" (1993 240), she does not deny-after the fashion of Rudolf Carnap-that Arnold Bennett is a genuine novelist, or even that he is a good one. Her point is that a novel like Bennett's The old Wives' Tale differs from Tristram Shandy and Pride and Prejudice in the way that members of the novel family differ from novels from which someone could learn the concept. She describes the difference as that between works for which human character becomes interesting in relation to something else, to property or class or the economic system, and works for which character is, as she says, interesting "in itself" $(235,240)$. Woolf's idea seems to be that learning from novels of the first kind is difficult, not because they are inferior, but because what makes them interesting, what makes them good novels, has no necessary connection to what makes them novels. It is as though applying the concept to them were a matter of their resemblance to things called novels in the past solely. Although by comparing such works to those of Sterne or Austen a young writer might be able to formulate a 
definition, it would bear little or no relation to what seems of fundamental importance for her, namely, what makes a novel like The Old Wives' Tale worth reading.

11 That in "Mr. Bennett and Mrs. Brown" Woolf is never able to explain what she means by character "in itself" poses no serious problem, since, if she is right about everyone's familiarity with the concept (238), all that is necessary for us to understand her are examples. And the examples in To the Lighthouse-published three years after Woolf's essay-provide a sufficiently definite picture of what she means (Woolf, 1981). Something like what we have called character in the past-that is, a force in each of the Ramsays and their guests that tries to impose itself on their social and material surroundings-seems to have moved into the novel's foreground, displacing the action. Or perhaps we will say that these manifestations of subjectivity just are the action, but to understand why Woolf considers them fundamental, why she thinks "the form of the novel" evolved specifically "to express character" (238), we will need to find questionable, cannot simply accept as a matter of course, that To the Lighthouse is over two-hundred pages long. That is, in Woolf's novel, character either expresses itself in a moment, as when Mr. Ramsay lifts his head to stare at Lily or when Charles Tansley boasts of never having been sick a day in his life, or else it expresses itself continuously, as with Mrs. Ramsay's proprietorial protectiveness of all males. What it does not do is express itself as the inevitable culmination of a chronological development, as in, say, a novel of education. Nothing could seem less inevitable, more accidental and arbitrary, than that Lily Briscoe's self-expressive act, her completing her painting, should occur only after the death of Mrs. Ramsay or at the same time that James reaches the lighthouse. Or in a sentence, the time required to read To the Lighthouse-its length-is not a material analogue of the fictional time required for the completion of its action. Why couldn't Woolf's novel be twice as long or fifty pages shorter?

I want to say that, if for some of us Woolf's novel is exemplary of novelness, that is because, even though neither short nor long, its length does not strike us as conventional. In other words, its length is not explained by Woolf's conformity to the expectations of the majority of readers or by the familiar definition of a novel as a fictional prose narrative that is long. On the contrary, the length of To the Lighthouse shows what the expression of character means, how it is related to our concept of a novel, not just in Woolf's work, but at any time. To recognize this meaning, we need to recall what numerous commentators have remarked, ${ }^{4}$ that Woolf's narrative oscillates between two distinct temporalities. According to the first, time is marked by constancy, recurrence, and duration, merging at moments with virtual timelessness, while in the second, time is fleeting, sentencing all creation to change, incompleteness, and decay. These two temporalities are what Mrs. Ramsay senses in the rhythmic flashes of the lighthouse-"It will end, it will end [...]. It will come, it will come" (63)-and what she hears in the waves' ceaseless monotony, "which for the most part [...] seemed consolingly to repeat [...], 'I am guarding you-I am your support,' but at other times [...] warned her whose day had slipped past in one quick doing after another that it was all ephemeral as a rainbow" (16). What commentators have not so frequently remarked is that conceiving time in these two forms cancels the first. In other words, the threat to constancy and duration, to what seems timeless, is just that, in reality, it is only one pole of a rhythmic oscillation, merely a moment in time. Acknowledging as much makes the issue that Woolf's novel must resolve-not so much at risk of becoming a bad novel, but of becoming a novel only conventionally-that of why to continue. In other words, if finishing her painting is meaningful for Lily, that cannot be because, unlike 
the island and house and Ramsays, her painting is going to endure. On the contrary, as Woolf tells us, "It would be hung in the attics [...]; it would be destroyed" (208). In fact, this destruction, which assumes the foreground in the novel's middle section, overtakes everything in To the Lighthouse: Mr. Ramsay's philosophy, Mrs. Ramsay's ageless beauty, Paul and Minta's burgeoning love, even Lily's aesthetic "vision," which, despite its momentary clarity, "a thousand forces did their best to pluck from her" when painting (19). That no chronology in To the Lighthouse ever culminates in anything lasting, anything timeless, makes the boundary between its story and a random distribution of moments appear artificial.

If continuing to paint, write, or read under such circumstances is to strike anyone as meaningful, then the expression of character must somehow cancel time. Unlike Sophia Baines's elopement in Bennett's The Old Wives Tale, which depends for its significance either on Sophia's circumstances later in the novel or on the historical circumstances of young women generally, only moments the significance of which does not depend on what comes before or after can make the two-hundred pages of Woolf's fiction worth traversing. Lily Briscoe describes such moments as having been "resolved [...] into simplicity" (160), suggesting that they result from some inessential complication or confusion being dispelled rather than from any significance being added. The idea is that whatever makes one moment's relation to another seem merely contingent, whatever suppresses affinities that might otherwise look obvious, is what the character of Mrs. Ramsay, with her beauty, imperiousness, and inept matchmaking-or perhaps in spite of these characteristics, as she just sits writing letters under a rock-renders immaterial. As Lily recalls, her own anger at Charles Tansley's misogyny seemed to "fall away like old rags" when Mrs. Ramsay looked over her spectacles at the two of them skipping stones across the water and laughed (160). Whatever we are to call this "astonishing power that Mrs. Ramsay had over one" (176), Woolf makes clear its family resemblance to the power that, even in changed circumstances-"as [Lily] walked along the Brompton Road, as she brushed her hair" (157) - prevents Lily's aesthetic vision from being forgotten: "[A]nd there it stayed in the mind affecting one almost like a work of art" (160). In both cases, relations that one comes to know merely in coming to know who or what someone or something is-Lily calls them "simple, obvious, commonplace" (52) - seem to have been momentarily laid bare, and despite their susceptibility to change and decay, restricting them to a definite time and place proves difficult. It is as though her sense of Mrs. Ramsay's character, of how "she brought together this and that and then this" (160), remained as fundamental to Lily's own character as her sense of distance, shade, mass, and line. Even years after Mrs. Ramsay's death, even after the war and Charles Tansley's passing from her life, when Lily resumes painting, she still "seemed to be sitting beside Mrs. Ramsay on the beach" (171).

And the length of To the Lighthouse threatens these revelations, rendering material our suspicion that they correspond to nothing more real, more lasting, than a mood, memory, or personal impression. What Mrs. Ramsay calls "a coherence in things" (105), the stable "shape" (161) that at moments Woolf depicts so vividly-"So that is marriage, Lily thought, a man and a woman looking at a girl throwing a ball" (72)invariably undergoes alienation a moment or page later, detaching itself from present surroundings and becoming the imposition of some character's subjectivity: "but this cannot last, [Mrs. Ramsay] thought, dissociating herself from the moment while they were all talking about boots" (104). It is because significance in To the Lighthouse always 
proves momentary in this way, is constantly being dispelled, that every new page questions it, giving the novel's length the same relation to what makes it worth reading that the picture in figure \#2 has to figure \#1 and that in Philosophical Investigations philosophy has to all of our concepts. A shape or coherence that seems obvious while under the power of Mrs. Ramsay's character, begins to blur as the pages turn, merging over the time of reading with before and after, until what seemed the sharpest imaginable boundary, that between the significant and the merely forgettable, resembles an undifferentiated continuum. The fact that, unlike Arnold Bennett's novels, the action of To the Lighthouse culminates in no stable relations-that the bowl of fruit whose colors and textures Mrs. Ramsay finds so satisfying gets disarranged a sentence later (108-09)-makes both Woolf's novel and the concepts we impose on it seem amorphous, indefinitely malleable. And no explanation, no theory of character or narrative, can bolster our confidence in them. For the question of why to continue-the question Lily asks of painting, "Why then did she do it?" (158) - no more wants an explanation than Lily's question, "What is the meaning of life?" (161), wants a definition of the word "life." What Lily's question wants is an example of why she paints, a recurrence of the moment when time stops and a world of significance materializes before her eyes, here and now. In To the Lighthouse, everyone's problem-Mrs. Ramsay's, Lily's, Woolf's, ours-is identical: how to discover in temporal relations what seems fundamentally important, and solving it means recognizing how character makes fictional prose narratives that are long worth reading. Or not.

Near the end of Part One of The Claim of Reason, Stanley Cavell makes the following remark:

If it is the task of the modernist artist to show that we do not know a priori what will count for us as an instance of his art, then this task, or fate, would be incomprehensible, or unexercisable, apart from the existence of objects which, prior to any new effort, we do count as such instances as a matter of course (Cavell, 1979b 123).

16 I want, in closing, to draw two conclusions about the relation of literature to philosophy, both of which follow from Cavell's remark.

17 First, what it means to have aesthetic concepts that I apply as a matter of course but that, if a particular application is questioned, I cannot explain, or not to others' satisfaction, is that, in a sense not equally true of numbers and games, our aesthetic knowledge is comprised of examples. That others do not understand me, that they find my explanation as confusing as what it is intended to explain, need not imply, as it almost certainly would with the words "number" and "game," that when speaking of literature, novels, or character, I do not know, or have only a very blurry idea, what I am talking about. Although Woolf fails to explain what she means by character "in itself," it does not follow that, in differentiating her concept of a novel from Arnold Bennett's on this basis, she is being anything less than acute. On the contrary, when reading To the Lighthouse, I feel quite confident she knows what she is talking about, and if challenged, I can identify the bases of my confidence, citing examples from the novel that differentiate character interesting in itself from character interesting in relation to something else. However, if despite the definiteness of this explanation, or perhaps because of it, others feel that my evidence is too limited, that no reliable conclusion about character "in itself" can be drawn from Woolf's novel alone, then a further difference from numbers and games is that citing more examples is unlikely to help. The cause of this loss of our common footing could be philosophical, having nothing to 
do with any differences in our aesthetic judgments. That is, we could be trying to determine what character means apart from any actual problem understanding Woolf, in which case the only explanation likely to satisfy us will be how the concept is applied at any time, making it look very blurry. However, if the cause of our disorientation is aesthetic, then just like our aesthetic knowledge generally, it will manifest itself in examples. Part of what Cavell's remark is intended to bring out is this concrete foundation underlying aesthetic disagreements. By interpreting the question of what kind of thing a putatively aesthetic object is, not as a question of family resemblances, but as a question of "what will count for us" as that kind of thing, he makes our aesthetic knowledge stand, teeter, and fall on the connection, or lack, between our concept of a novel and our judging something to be-to count as-a good one. That a single example can lay bare this connection, that a novel can function as exemplary, means that my inability to make my application of aesthetic concepts understandable may result, not from confusion or lack of training, but from seeing more in a particular example than others see. And in such circumstances bringing our aesthetic practices into conformity will prove as difficult as getting others to see what is of fundamental importance to them or getting myself to forget what I have seen.

And my second conclusion follows from this first, namely, that what it means to have aesthetic concepts I apply confidently but that, if a particular application is questioned, I can explain only by getting others to see what I see, is that, in a sense not equally true of numbers and games, there is no impersonal knowledge of literature. Part of Wittgenstein's point in turning us away from explanations and toward examples is that, to the philosophical question of what gives our aesthetic concepts their shape, the only frank answer is that $I$ do. Only in relation to a concrete human subject, to what Woolf calls human character, can a concept like literature, which begins to look blurry as soon as we try to formulate its definition, be resolved into simplicity by examples of the kind from which we learned it. But to concede as much makes aesthetic concepts seem reducible to acculturation alone, as though unrelated to anything external, while the point of philosophical questioning is to expose all such parochialism, reminding those who use words like "literature," "novel," and "character" that, on the vast continuum of written and oral narratives, the examples from which we learned these words comprise only a handful of randomly distributed points. If, as Cavell implies, "what will count for us" as an example of literature depends for its comprehensibility on examples of just this limited kind, then instead of looking blurry, our concept begins to look confining, almost as though logically circular. But Cavell's paradox is that this same "matter of course" deployment of the concept also enables a work like To the Lighthouse to show us that "we do not know what will count," that our open-ended, unselfconscious use of words like "literature," "novel," and "character" signifies nothing more than that those with whom we communicate do not ordinarily question them. If anything counts as literature, that is not because others deploy the concept as I do. It is because certain examples function for me as exemplary, laying bare what $I$ mean, what is of fundamental importance to my using the word at any time. When Lily Briscoe wonders, "Why then did she do it?" I do not know whether she is asking a philosophical or aesthetic question. That, as Wittgenstein remarks, "Explanations come to an end somewhere" (Wittgenstein, 2009 6) does not justify my failure to explain myself, but it does redirect my attention toward examples, after which there is a great deal I will feel no need to say. 


\section{BIBLIOGRAPHY}

ADORNO, Theodor. "Reconciliation under Duress." Translated from the German by Rodney Livinstone. Aesthetics and Politics. Ed. Ronald Taylor. New York: Verso, 1998, p. 151-76.

BARTHES, Roland. Writing Degree Zero. Translated from the French by Annette Lavers and Colin Smith. New York: Hill and Wang, 1977.

BENNETT, Arnold. The Old Wives' Tale. New York: Penguin, 2007.

BERRY, Ralph M. "In Which Henry James Strikes Bedrock.” Ordinary Language Criticism: Literary Thinking after Cavell after Wittgenstein. Eds. Kenneth Dauber, and Walter Jost. Evanston, Illinois: Northwestern University Press, 2003, p. 245-58.

CARNAP, Rudolf. "The Elimination of Metaphysics through Logical Analysis of Language." Logical Positivism. Ed. A. J. Ayer. Glencoe, IL: Free Press, 1959.

CAVELL, Stanley. Must We Mean What We Say? Cambridge, UK: Cambridge University Press, 1969.

CAVELL, Stanley. The World Viewed. Cambridge, MA: Harvard University Press, 1979a.

CAVELL, Stanley. The Claim of Reason. New York: Oxford University Press, 1979b.

FORSTER, E. M. Aspects of the Novel. New York: Harcourt Brace Jovanovich, 1927.

JAMES, Henry. "The Art of Fiction." The Art of Criticism: Henry James on the Theory and Practice of Fiction. Eds. William Veeder, and Susan M. Griffin. Chicago: University of Chicago Press, 1986, p. 165-96.

SEARLE, John R. "Reiterating the Difference: A Reply to Derrida." Glyph 1. Eds. Samuel Webster, and Henry Sussman. Baltimore: Johns Hopkins University Press, 1977, p. 198-208.

SHEEHAN, Paul. "Time as Protagonist in To the Lighthouse." The Cambridge Companion to To the Lighthouse. Ed. Allison Pease. New York: Cambridge University Press, 2015, p. 47-57.

STEIN, Gertrude. "Composition as Explanation." Selected Writings of Gertrude Stein. Ed. Carl Van Vechten. New York: Vintage, 1990, p. 511-23.

WILLIAMS, Raymond. Marxism and Literature. Oxford: Oxford University Press, 1977.

WITTGENSTEIN, Ludwig. Philosophical Investigations. Translated from the German by G.E.M. Anscombe, P.M.S. Hacker, and Joachim Schulte. 4th ed. revised. Malden, MA: Wiley-Blackwell, 2009.

WOOLF, Virginia. To the Lighthouse. New York: Harcourt, 1981.

WOOLF, Virginia. "Mr. Bennett and Mrs. Brown." A Bloomsbury Group Reader. Ed. S.P. Rosenbaum. Cambridge, MA: Blackwell, 1993, p. 233-49.

\section{NOTES}

1. The relation of self-knowledge to knowledge is arguably the overarching theme of Cavell's interpretation of Wittgenstein's Philosophical Investigations, but it becomes explicit in his account of Wittgenstein's use of the first-person plural pronoun "we." (See Cavell, 1969 1-72, 238-66; 1979b 65-85.) 
2. Of direct relevance for the issues raised here is Cavell's idea that "aesthetic judgment models the sort of claim entered by [...] philosophers" who, like Wittgenstein, "appeal to what 'we' say and mean," and that the familiar lack of resolution in aesthetic disagreements, rather than grounds for suspicion, reveals the kind of rationality that both aesthetics and this philosophical appeal have. (See Cavell, 1969 86-96)

3. For Cavell's use of the adjective "exemplary," see 1969 94, 178-79; 1979b 178. In Cavell's philosophy, learning what a concept means, both in the case of a child's first acquisition of the concept and also an adult's later discovery of new ranges of application of it, is dependent on applications that strike the learner as exemplary (1979b 168-180). Cavell's account of the changes in art effected by modernism turns on this idea that a single example of an aesthetic concept can prove exemplary, that is, can disclose the concept's meaning at any time (1979a 109-10).

4. For a recent example, see Sheehan, 2015.

\section{ABSTRACTS}

Before puzzling over some possible conjunction between literature and philosophy, one has to agree on what such concepts mean. However, as soon as one wonders about their definitions, concepts like "literature" or "the novel" on the one hand, or "philosophy" or even "concept" on the other, prove all too elusive. If one thinks they know what a novel is, it proves virtually impossible to freeze a suitable definition of the aesthetic concept. The reason for that impossibility might be that philosophy's mission, to the extent that it reflects upon concepts, is somehow to blur them. Yet this article aims to show that it is precisely in that sense that literature, through the example of the novel, is in itself philosophical to the degree that what defines the novel is a self-reflexive interrogation of what makes it so. With the example of Virginia Woolf's To the Lighthouse, the article concludes that there might be no intrinsic knowledge of our (aesthetic) concepts outside examples.

Avant de s'interroger sur une éventuelle conjonction entre littérature et philosophie, encore faut-il s'entendre sur ce que recouvrent ces concepts. Or dès qu'on soulève la question de leur définition, les concepts de "littérature » ou de "roman » d'un côté, de "philosophie » voire de « concept » de l'autre, s'avèrent éminemment fuyants. Si on pense savoir ce qu'est un roman, en arrêter une définition acceptable s'avère quasiment impossible. La raison en est que la philosophie, en tant qu'elle s'interroge sur des concepts, a pour mission de les brouiller. Or, cet article vise à démontrer que c'est précisément en ce sens que l'écriture littéraire, à travers l'exemple du roman, est philosophique, puisque c'est aussi le propre du roman, à l'instar de To the Lighthouse de Virginia Woolf, de s'interroger sur ce qui le définit en tant que tel. De sorte qu'il n'y a de connaissance possible que dans l'exemple.

INDEX

Keywords: Wittgenstein, philosophy, novel, concept, definition, time, Virginia Woolf

Mots-clés: Wittgenstein, philosophie, roman, concept, définition, temps, Virginia Woolf 
AUTHOR

RALPH M. BERRY

Florida State University 